\title{
Redesign of Economic Learning Based on 4C Skills in Senior High School at Padang
}

\author{
Rita Syofyan ${ }^{1 *}$, Oknaryana $^{2}$ \\ ${ }^{1,2}$ Universitas Negeri Padang, Padang, Indonesia \\ ${ }^{*}$ Corresponding author. Email: ritasyofyanunp@gmail.com
}

\begin{abstract}
The design of economic learning planning based on $4 \mathrm{C}$ learning skills is a problem, this is in response to the latest policy set by the Minister of Education and Culture related to the preparation of learning implementation plans that began to be implemented at the beginning of the 2020 learning year. The process must include these $4 \mathrm{C}$ skills in learning. The problems found in the field of teachers are still not ready and skilled in concocting learning that includes $4 \mathrm{C}$ skills, starting from the aspects of planning, implementation and evaluation. The purpose of this research is to develop learning planning, implementation in the form of teaching materials containing $4 \mathrm{C}$ skills and evaluations that can reflect the skills of $4 \mathrm{C}$-based students which are expected to form a generation that has competencies that are able to compete in the future.
\end{abstract}

Keywords: Redesign of learning, 4C skills, Learning economics.

\section{INTRODUCTION}

The Merdeka Belajar Program is a new policy launched by the ministry of education and culture. This policy package will provide opportunities for teachers to be creative in developing learning activities. In principle, a change in the educational paradigm so that it becomes more autonomous with an innovative learning culture, which is expected to form competences according to the needs of the times.

Competence can be owned by training, development and learning. preparing individuals who can compete in the future is certainly the task of every component of education in an environment where individuals learn and develop. One who has a big role is an educator or teacher. Teachers must ensure students have 21st century skills known as 4C, namely Communication, Collaborative, Critical Thinking and Problem Solving and Creativity and Innovation

The progress of the 21 st century can be seen by the amount of information available anywhere and can be accessed at any time, increasingly advanced computerized technology, technology that is starting to replace routine jobs, and communication that can be done anywhere, anytime and anywhere. This certainly has a direct impact on education, one of which is the latest policy set by the Minister of Education and
Culture related to reflection on the achievement of targets in the learning implementation plan which was implemented at the beginning of the 2020 learning year. The reflection process must include these $4 \mathrm{C}$ skills in learning [1].

Based on preliminary observations made on economics teachers in the city of Padang, there are problems regarding the application of $4 \mathrm{C}$ skills, the teacher has not been able to integrate $4 \mathrm{C}$ skills in economic learning and the teacher finds it difficult to determine the right learning method to help form $4 \mathrm{C}$ skills.

From the explanation above, the specific purpose of this research is to design an Economic Learning Planning Model, Teaching Materials and evaluation which includes the 4C approach, namely Creative, Critical thinking, Communicative, and Collaborative. This is very important in learning because it will have an impact on the implementation and achievement of learning objectives [2]. The first step in this research is to select an economic material that has a high level of difficulty, based on 21 st century skills, what K-13 really wants to aim at is not just material transfer. The importance of mastering $4 \mathrm{C}$ as a means of achieving success, especially in the 21 st Century, a century in which the world is developing very fast and dynamic. Mastery of 21 st century skills is very important; $4 \mathrm{C}$ is a 
type of soft skill that in daily implementation is much more useful than just mastering hard skills.

This research is interesting and important to do because it is related to the quality of learning and forming an independent generation of learning as expected, if this is not formulated, the teacher will find it difficult to compile and implement a learning implementation design model and integrate learning material with 4C skills, and measure student competence with the right evaluation is as expected, this will certainly affect the skills of the millennial generation in the future [3].

\section{METHOD}

This research is research and development (Researce and Development), one of the research methods used to produce certain products, and to test its effectiveness. The orientation of the study was to design an economic learning plan based on the $4 \mathrm{C}$ approach.

The development model in this study follows a development model adapted from the ADDIE instructional design model which includes the analysis (analysis), design (design), development (develop), implementation (implement) and evaluation (evaluate) steps which are combined according to development research steps. recommended by Redhana [4].

\section{RESULTS AND DISCUSSION}

Learning design refers to a set of activities to design and develop learning activities to achieve specific learning objectives with the success of that learning. Learning design is the development of a learning system and its implementation system including facilities and procedures to improve the quality of learning. Learning design is a systematic process of developing learning packages using learning theory and learning theory to ensure quality learning [5]. The steps to identify and analyze problems in this study were carried out by studying literature and field studies and conducting FGDs with several economics teachers with the aim of identifying and discussing and finding solutions to existing problems [6]. Researchers made observations to see a series of learning processes carried out in the classroom. From the results observation can be concluded that the learning process is still conventional, variations in learning methods cannot be developed so that fun and meaningful learning has not been achieved optimally. The use of the lecture method still dominates the learning method so that it has implications for the teacher-centered learning process. The demands in the independent era require teachers to apply $4 \mathrm{C}$ skills in learning with the aim of applying creativity, collaboration, communication and critical thinking skills, with existing learning teachers find it difficult to achieve the educational goals of the independent learning era.

This study uses the ADDIE concept (Analysis, Design, Development, Implementation and Evaluation) [7], with the following analysis on Table 1.

Based on the research results above, it can be concluded that learning design is the most important thing in achieving learning objectives. Learning design must be arranged in accordance with the objectives to be achieved, demanding $4 \mathrm{C}$ skills requires teachers to be able to collaborate and relevant between the material and the $4 \mathrm{C}$ skills. Therefore, the teacher must use active learning methods that will help in achieving learning objectives, besides that it must be supported by clear material, valid evaluation and a coherent learning structure. Larmuseau [8] explains that learning design is centered on individual learning, has stages that have far and near ranges, are systematic and use a system approach to human knowledge and learning. From the opinion of several experts regarding learning design, it is known that in designing learning not only lesson plans, but designing systematic learning stages that have been tested for their effectiveness so that they can be used properly, because they develop good learning designs. can guarantee the quality of every learning that is carried out [9].

In addition, teachers must take appropriate learning approaches with students, $4 \mathrm{C}$ skills require teachers to be more attentive and use more intensive classroom management so that the character of students can be recognized and recognized well. This is in accordance with Sipayung [10] opinion which states that a wellcreated learning design can minimize problems that often occur in learning, both in terms of teacher performance, achievement of learning objectives and others. In addition, in developing learning designs, it is expected that you can understand individual characteristics, so that the designs created can be understood.

\section{CONCLUSION}

Based on the research results, it can be concluded that learning design is very important in achieving learning objectives, so learning activities must be clear and measurable, and in integrating $4 \mathrm{C}$ skills in teacher learning, they must be able to produce student thinking activities that are useful to help bring out students' critical thinking communication, cooperation and creativity characterized by the ability to solve problems, make decisions, analyze assumptions, evaluate, and create. 
Table 1. ADDIE Concept Results

\begin{tabular}{|c|c|c|c|}
\hline Number & Activity & Description & Output \\
\hline 1 & Analysis & $\begin{array}{l}\text { Choose basic competencies in } \\
\text { planning economic learning } \\
\text { and analyze material }\end{array}$ & $\begin{array}{l}\text { The basic competencies chosen were "Price Index and } \\
\text { Inflation". The teacher stated that this material was the } \\
\text { most difficult material to relate to } 4 \mathrm{C} \text { skills. Besides } \\
\text { this material, students' understanding or analysis is } \\
\text { quite long compared to other materials. }\end{array}$ \\
\hline 2 & Design & $\begin{array}{l}\text { Creating an economic learning } \\
\text { design based on the } 4 \mathrm{C} \\
\text { approach }\end{array}$ & $\begin{array}{l}\text { Lesson plans made in general are as follows: } \\
\text { - The teacher provides the opportunity to identify } \\
\text { as many things as possible that have not been } \\
\text { understood, starting from factual questions to } \\
\text { hypothetical questions. This question must be } \\
\text { related to the material price index and inflation. } \\
\text { Students are formed in several groups to discuss, } \\
\text { collect information, presentations, and exchange } \\
\text { information about the price index and inflation. } \\
\text { Students present the results of group or individual } \\
\text { work classically, express their opinion on the } \\
\text { presentation made then respond back by the } \\
\text { group or individual who presents it. } \\
\text { Teachers and students make conclusions about } \\
\text { what they have learned related to the price index } \\
\text { and inflation. Students are then given the } \\
\text { opportunity to ask again things that have not been } \\
\text { understood. }\end{array}$ \\
\hline 3 & Development & Expert Appraisal & $\begin{array}{l}\text { Validating existing learning designs with lecturers who } \\
\text { are experts in their fields }\end{array}$ \\
\hline 4 & Implementation & $\begin{array}{l}\text { Implement the learning plan } \\
\text { that has been developed }\end{array}$ & $\begin{array}{l}\text { The learning design that has been compiled is } \\
\text { implemented in classroom learning. }\end{array}$ \\
\hline 5 & Evaluation & FGD & $\begin{array}{l}\text { Based on the results of the FGD, there were several } \\
\text { evaluations of the implementation of the learning } \\
\text { design that had been carried out, namely in terms of } \\
\text { learning activities, material and closing activities. In } \\
\text { learning activities, in addition to delivering material, } \\
\text { the teacher must integrate 4C skills, in terms of } \\
\text { communication, the teacher states that students have } \\
\text { difficulty expressing opinions or asking questions } \\
\text { because the material is not clearly understood. The } \\
\text { solution given is to use a variety of learning methods } \\
\text { and approaches, and teach students to be able to work } \\
\text { together or collaborate, in learning students are asked } \\
\text { to help each other and care for the environment, if } \\
\text { there are other students who don't understand, the } \\
\text { teacher directs students who understand helps, in } \\
\text { addition to forming cooperation, this also trains } \\
\text { students' communication and critical thinking. From } \\
\text { the material and learning evaluation, based on the } \\
\text { results of the FGD there were improvements in several } \\
\text { question items, the questions were more directed at } \\
\text { levels C4, C5 and C6, namely analysis, evaluation and } \\
\text { creation. }\end{array}$ \\
\hline
\end{tabular}
the teacher's skills in training and directing students to be more active in learning, material provision must be accompanied by student center learning methods, which require students to more 


\section{REFERENCES}

[1] Ministry of Education and Culture, Law No. 20 of 2003 Concerning the National Education System. Jakarta: Depdiknas, 2003

[2] A.H. Abdullah, N.L.Z, Abidin, \& M. Ali, "Analysis of students' errors in solving Higher Order Thinking Skills (HOTS) problems for the topic of fraction". Asian Social Science, 11 (21), 133. 2015

[3] P.E. Gundersen, "How Does the High School Redesigned Learning Space Influence Collaboration, Communication, Creativity, And Critical Thinking", Seton Hall University Dissertations and Theses (ETDs). 2019

[4] I.W. Redhana, "Developing 21st Century Skills in Learning Chemistry", Journal of Chemical Education Innovation, Vol 13, No 1, Pages 2239 225. 2019.

[5] M.W. Mulholland, \& L.J. Greenfield, The University of Michigan. In Archives of Surgery. 2003.

[6] E. Prihadi, "4c Skills Development through the Comment Poster Method on Pie and Character Subjects (Research at SMA 26 Bandung)", Passion Of The Islamic Studies Center JPI_Rabbani. 2018

[7] B.A. Jones, ADDIE model (Instructional design). 2014

[8] C. Larmuseau, J. Elen, \& F. Depaepe, "The influence of students 'cognitive and motivational characteristics on students' use of a 4C/ID-based online learning environment and their learning gain", Proceedings of the 8th International Conference on Learning Analytics and Knowledge, (pp. 171-180). 2018

[9] A. Widowati, W.S, Wibowo, \& P. Anjarsari, "Optimizing Natural Potential as a Scientific Problem Orientation to Realize Meaningful Science Learning", Journal of Community Service for Mathematics and Natural Sciences and Mathematics and Natural Sciences Education, 1 (1), 17-22. 2017.

[10] D.H. Sipayung, R.A. Sani, \& H. Bunawan, "Collaborative Inquiry For 4C Skills. In 3rd Annual International Seminar on Transformative Education and Educational Leadership". AISTEEL 2018 Atlantis Press. 2018 